مجلية النبحوث المالية والنتجاريةّة

المجلد (22) - العدد الرابع - أكتوبر 2021

Vector auto-regressive model (VAR) results' versus auto-regressive distributive lags model (ARDL) results'.

Rania Ramadan Moawad

Faculty of Economics and International Trade

The Egyptian Chinese University

rramdan@ecu.edu.eg

مقارنة بين نتائج تطبيق كل من نموذج متجه الانحدار الذاتي و نموذج الإنجاء

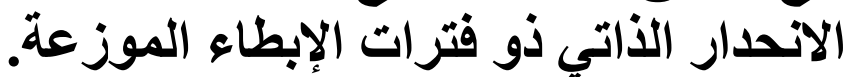

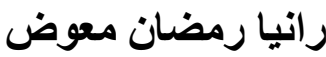

كلية الاقتصاد و التجارة الدولية

الجامعة المصرية الصينية 


\section{مقارنـة بين نتائج تطبيق كل من نموذج متجـه الانحدار الأاتي و نموذج

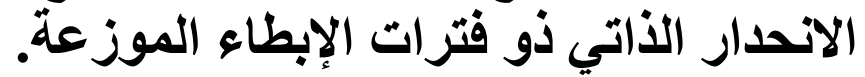

الملخص:

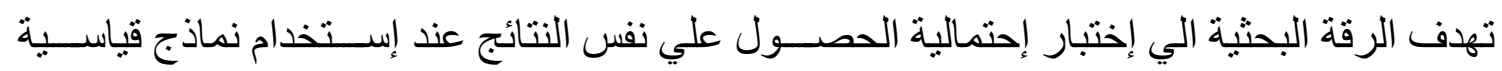

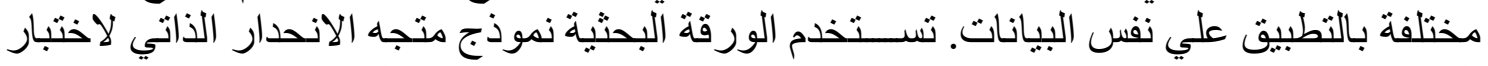

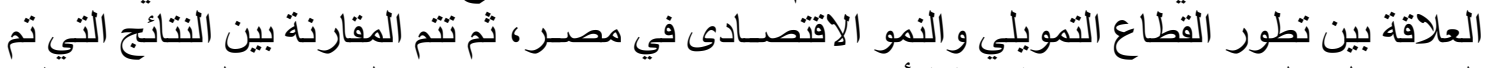

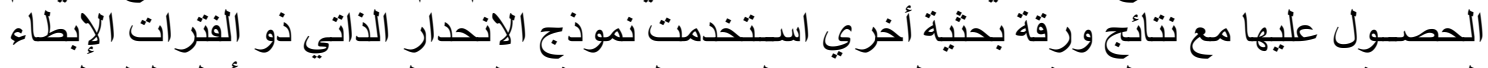
الموزعة لاختبار نفس العلاقة ونفس البيانات. خلصت المقات المقارنة بنطابق النتائج في الأجل الطويل.

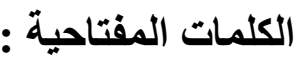

نموذج متجه الأنحدار الذاتي، نموذج النحدار الذاتي ذوفترات الإبطاء الموز عة، القطاع التمويلي،

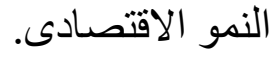




\title{
Vector auto-regressive model (VAR) results' versus auto-regressive distributive lags model (ARDL) results'.
}

\begin{abstract}
The paper aims to test the possibility of getting the same results when applying two different econometric models ${ }^{1}$ in testing the relation between the development of financial sector and the economic growth in Egypt. The paper examines the relation between the improvement of financial segment and the economic growth in Egypt to check the relation's existence and to determine its direction using the vector autoregressive model VAR. The paper then compares the results obtained with the results of other published paper using auto-regressive distributed lags model ARDL to test the same relation in Egypt. The main finding of this study is that results were the same in the long-run.
\end{abstract}

Keywords-Financial development; Economic growth, ARDL, Vector error correction model, Co-integration.

JEL codes: A12, C01, C13, C22, C51, E51, R15, 043.

\section{Vector auto-regressive model (VAR) results' versus auto-regressive distributive lags model (ARDL) results'.}

${ }^{1}$ after testing the possibility of data to be treated with different models, the researcher found that the ${ }^{1}$ data can be treated using VAR and ARDL models. 


\begin{abstract}
The paper aims to test the possibility of getting the same results when applying two different econometric models ${ }^{2}$ in testing the relation between the development of financial sector and the economic growth in Egypt. The paper examines the relation between the improvement of financial segment and the economic growth in Egypt to check the relation's existence and to determine its direction using the vector autoregressive model VAR. The paper then compares the results obtained with the results of other published paper using auto-regressive distributed lags model ARDL to test the same relation in Egypt. The main finding of this study is that results were the same in the long-run.
\end{abstract}

Keywords-Financial development; Economic growth, ARDL, Vector error correction model, Co-integration.

JEL codes: A12, C01, C13, C22, C51, E51, R15, O43.

\title{
1. Introduction
}

The relation between the financial segment improvement and the economic growth has been treated by many researchers.

The problem of research is to test the relation between the economic growth and the sources of financing development in Egypt using the vector autoregressive model; then to compare results obtained by the research with results obtained by other published research which has tested the same relation using other econometric model ARDL but the same data.

The organization of the paper is: section 2 displays the previous literature on the relation between the financing sector development and economic growth. Section 3 displays the paper methodology and section 4 is the paper applied part. Section 5 shows the results, and section 6 is the conclusion.

\section{Previous literature}

We have different sides for viewing and studying the relationship between the financial sector development and the macroeconomic variables such as economic growth.

The first side believes that financial sector play an important role affecting economic growth. The other side believes that there is no causal relation running from financial sector to economic growth. While other side believes that financial sector is affected by economic growth rather than affecting it (Alomar, 2009)

${ }^{2}$ after testing the possibility of data to be treated with different models, the researcher found that the ${ }^{2}$ data can be treated using VAR and ARDL models. 
Many researchers have studied the effect of the banking sector development on the economic growth and found a positive relationship (Coplman, 2000) (Thorsten, 2000) (Hofman, 2001) (Rousseau, 2002) (Alomar, 2002) (Caridi, 2004) (Mercan and Ismet, 2013) (Nalinniprava, 2019).

On the other side a researcher has found the relationship to be negative and insignificant in the long term but significant and negative in the short term (Eugene Iheanacho, 2016). Other study proved that, the relationship is no longer strong in recent data as it was in old data (Rousseau and Wachtel, 2009).

Other recent study has studied the relation between the economic growth and a variety of sources of financing, whether from the banking sector or the various instruments offered by the stock market in Egypt using ARDL model and found that the relation exists in the short and long terms. In the long term, the development of the financing sector leads to the development of economic growth, and in the short term, there is a link between the improvement of the banking sector and economic growth. (Rania, 2020).

A researcher has found an inverted U-shaped form (financial development exerts a positive effect on economic activities until a certain threshold and after that, the link becomes negative). (Juliana, 2020)

After this literature review, the researcher found that it is necessary to test the relation between the development of the financial sector and the economic growth using different models ${ }^{3}$ to get a path for improving economic growth.

\section{Research methodology}

The econometric methodology used to test the link between the improvement of the financial segment and the economic growth for the period 1980-2015 is the VAR model.

\subsection{VAR model}

\subsubsection{VAR methodology}

Co-integration method has been used, which includes both the autoregressive model and the error correction model. Then Granger's causality test will be performed to check the causality between the variables of the model. 


\subsubsection{Variables and data sources}

Annual data for the period 1980-2015 will be used. The variables used are:

GDPeg: real growth rate

CReg: Credit directed to the private sector as a ratio of GDP

TReg: The rate of trade openness

STeg: Capital market capitalization as a ratio of GDP

These data were gotten from the official website of the World Bank, Database of Financial Development. (World Bank, 2016), as well as the official website of the International Monetary Fund and the data site www.theglobaleconomy.Com /index_api.php.

The study uses the private credit variable as the ratio of GDP and the capital market capitalization as a ratio of GDP to reflect the development of the financing sector, the GDP growth rate to express economic growth. The study will also use the variable of trade openness as a control variable.

\subsubsection{VAR model framework}

The auto-regression vector model will be used in the reduced form as follows:

$\mathrm{Y}_{\mathrm{t}}=\mathrm{B}_{1} \mathrm{Y}_{\mathrm{t}-1}+\mathrm{B}_{2} \mathrm{Y}_{\mathrm{t}-2}+\ldots \ldots+\mathrm{B}_{\mathrm{p}} \mathrm{Y}_{\mathrm{t}-\mathrm{p}}+\mathrm{E}_{\mathrm{t}}$

Where:

$\mathrm{Y}_{\mathrm{t}}=\left[\begin{array}{llll}\mathrm{GDPeg}_{\mathrm{t}} & \mathrm{Creg}_{\mathrm{t}} & \mathrm{TReg}_{\mathrm{t}} & \mathrm{steg}_{\mathrm{t}}\end{array}\right]$ which is a vector that includes the four preceding defined variables

$\mathrm{B}_{\mathrm{i}}$ : represents the transaction matrix and its dimensions $\mathrm{KxK}$

$\epsilon$ : Random error vector where $\mathrm{E}(\epsilon)=0$

$P$ : The number of time lags

t: time

$\mathrm{K}$ : The number of variables.

\section{Model steps}

- Stationarity tests: They have been performed using the Augmented Dicky-Fuller (ADF) models, and since the use of the differences to stabilize these chains cause the loss of a lot of information related to the behavior of these variables in the long term, we used co-integration to overcome this problem.

- Co-integration test: The only method to study a relation in the long term between non stationary variables and integrated of degree (n) is to associate these variables with a co-integration relationship.

- Error correction vector: It is used to test the presence of a relationship in the short term. Since the co-integration test indicates a long-term equilibrium relationship between the variables, while the short term may be unbalanced, the random term can be treated as the equilibrium error and used to link the 
behavior of the variable in the short term and its long-term value (Gujarati, 2003).

- Granger causality test: Granger's causality test will be performed to test the causality between the variables of the model.

\section{Applied study}

\subsection{Stationarity test}

By doing the Stationarity test we find that the independent variable is integrated of order 0 , one of the independent variables is integrated of order 0 and the other two variables are integrated of order 1.

Table 1: staionarity test

\begin{tabular}{|l|l|l|l|}
\hline Variable & $\begin{array}{l}\text { Mackinnon } \\
\text { (1996) one- } \\
\text { sided p- } \\
\text { values }\end{array}$ & $\begin{array}{l}\text { ADF test } \\
\text { Statistic }\end{array}$ & $\begin{array}{l}\text { Order of } \\
\text { integration } \\
\text { of the } \\
\text { variable }\end{array}$ \\
\hline GDPEG & -2.948404 & -3.374138 & $\mathrm{I}(0)$ \\
\hline CREG & -3.646342 & -6.781007 & $\mathrm{I}(1)$ \\
\hline TREG & -2.957110 & -3.481961 & $\mathrm{I}(0)$ \\
\hline STEG & -3.261452 & -3.487187 & $\mathrm{I}(1)$ \\
\hline
\end{tabular}

In this situation we can track the co-integration of Johansen and we can get the VECM.

\subsection{Lag order specification}

Table 2: VAR Lag Order Selection

\begin{tabular}{ccccccc}
\hline \hline Lag & LogL & LR & FPE & AIC & SC & HQ \\
\hline \hline 0 & 25.93966 & NA & $1.60 \mathrm{e}-06$ & -1.994514 & -1.796143 & -1.947784 \\
1 & 67.10656 & 63.62158 & $1.68 \mathrm{e}-07$ & -4.282415 & -3.290558 & -4.048763 \\
2 & 93.77112 & $31.51266^{*}$ & $7.54 \mathrm{e}-08$ & -5.251920 & $-3.466578^{*}$ & -4.831347 \\
3 & 118.1781 & 19.96932 & $5.80 \mathrm{e}-08^{*}$ & $-6.016188^{*}$ & -3.437360 & $-5.408694^{*}$ \\
\hline \hline
\end{tabular}

* indicates lag order selected by the criterion

According to Schwarz information criterion and sequential modified LR test statistic (each test at 5\% level) criteria; the model will use two time lags for its variables.

\subsection{Cointegration test}


Due to the non-stationary of the variables, the Johansen co-integration test was performed to test the possibility of a relation in the long term between the variables studied. The result was the presence of a relation in the long term at a significant level $95 \% .^{4}$

Table 3: Cointegration test

\begin{tabular}{|c|c|c|c|c|}
\hline \multicolumn{4}{|c|}{ Series: GDPEG D(CREG) D(STEG) TREG } & \multirow[b]{3}{*}{ Prob.*: } \\
\hline Hypothesized & & Trace & 0.05 & \\
\hline No. of CE(s) & Eigenvalue & Statistic & Critical Value & \\
\hline None $*$ & 0.929431 & 94.60403 & 47.85613 & 0.0000 \\
\hline At most $1 *$ & 0.633864 & 36.27841 & 29.79707 & 0.0078 \\
\hline At most 2 & 0.366937 & 14.17387 & 15.49471 & 0.0783 \\
\hline At most $3 *$ & 0.170624 & 4.115800 & 3.841466 & 0.0425 \\
\hline
\end{tabular}

\subsection{Vector error correction model VECM}

The vector error correction model was estimated and the error correction coefficient was a negative value of -0.660750 but insignificant, which indicates that there isn't a relationship in the short term between the model variables.

Table 4: VECM Estimates

\begin{tabular}{|l|l|l|l|l|}
\hline \multicolumn{4}{|l|}{ VECM Estimates } \\
\hline \multicolumn{4}{|l|}{ Standard errors in ( ) \& t-statistics in [ ] } \\
\hline Error Correction: & D(GDPEG) & (CREG,2) & D(STEG,2) & D(TREG) \\
\hline CointEq1 & -0.660750 & -0.105225 & 0.084271 & -0.097617 \\
\hline & $(0.13385)$ & $(0.02690)$ & $(0.16866)$ & $(0.06639)$ \\
\hline & {$[-4.93646]$} & {$[-3.91104]$} & {$[0.49966]$} & {$[-1.47029]$} \\
\hline & 0.923701 & 0.721673 & 0.123677 & 0.376574 \\
\hline R-squared & 0.866477 & 0.512927 & -0.533565 & -0.090996 \\
\hline Adj. R-squared & 16.14183 & 3.457191 & 0.188175 & 0.805385 \\
\hline F-statistic & \multicolumn{4}{|l}{} \\
\hline
\end{tabular}

\subsection{Granger causality}

To study the causal relation between variables of the model; Granger causality test is performed. We can notice that the improvement of the financial segment can affect the economic growth in the long run and that there is a mutual effect between development of capital markets and economic growth.

Table 5: granger causality test

\begin{tabular}{|l|l|l|l|}
\hline Dependent variable & $\begin{array}{l}\text { independent } \\
\text { variable }\end{array}$ & $\begin{array}{l}\mathrm{p}- \\
\text { value }\end{array}$ & Decision \\
\hline \multirow{3}{*}{ Gdpeg } & $\mathrm{D}($ creg $)$ & $\mathbf{0 . 0 8}$ & Reject Ho \\
\cline { 2 - 4 } & Treg & $\mathbf{0 . 1 9}$ & Reject Ho \\
\cline { 2 - 4 } & $\mathrm{D}(\mathrm{steg})$ & $\mathbf{0 . 0 1}$ & Reject Ho \\
\hline
\end{tabular}




\begin{tabular}{|l|l|l|l|}
\hline \multirow{4}{*}{ (creg) } & Gdpeg & $\mathbf{0 . 0 7}$ & Reject Ho \\
\cline { 2 - 4 } & Treg & 0.96 & Accept Ho \\
\cline { 2 - 4 } & D(steg) & 0.64 & Accept Ho \\
\hline \multirow{3}{*}{ Treg } & Gdpeg & 0,88 & Accept Ho \\
\cline { 2 - 4 } & D(creg) & $\mathbf{0 . 0 5}$ & Reject Ho \\
\cline { 2 - 4 } & D(steg) & 0.70 & Accept Ho \\
\hline \multirow{3}{*}{ (steg) } & Gdpeg & 0.67 & Accept Ho \\
\cline { 2 - 4 } & D(creg) & 0.22 & Accept Ho \\
\cline { 2 - 4 } & Treg & 0.55 & Accept Ho \\
\hline
\end{tabular}

It is clear from the above:

- The existence of a causal relationship that moves from the private credit variable as a ratio of the gdp to the real gdp growth rate at a significant level of $10 \%$. $(90 \% \text { confidence level })^{5}$

- The existence of a causal relationship that moves from the capital market capitalization variable as a ratio of the gdp to the growth rate of real gdp at a significant level of $1 \%$.

- The existence of causal relationship moving from the variable growth rate of real gdp to the variable capital market capitalization as a ratio of gdp at a significant level of $10 \%$.

- The existence of a causal relationship from the private credit variable as a ratio to the gdp to the rate of trade openness.

\section{$5 \quad$ Results}

- $\quad$ The result of the co-integration test was the existence of a long term relation between the variables at a significant level $95 \%$.

- $\quad$ The VECM shows that there isn't a relation in the short term between the model variables.

- $\quad$ The granger causality test indicates the existence of relations going from both the bank sector and the capital market sector to the economic growth rate. There is also a relation going from the economic growth to the capital markets.

\section{Conclusions}

- Comparing results of this paper with previous one we found the following: using ARDL model we have :

- In the long term, the improvement of the financing segment leads to the variation of economic growth. 
- The error correction coefficient is significant and takes a negative value of 0.84 indicating the speed of return to the long-term equilibrium. This means that any deviation from the long-term equilibrium path between the explanatory variables and the independent variable in period $t-1$ will be remunerated in period $t$.

o SO we can say that in the short term, there is a relationship between the improvement of the banking segment and economic growth.

- The result of Granger's causality test result was the significance of the coefficient of the error term, indicating a causal relationship moving from the explanatory variables to the dependent variable in the long term. (Rania , 2020)

- Using two different econometric models to test the existence of the relation between the improvement of the financial segment and the economic growth in Egypt, has contributed to the same result which is the existence of long run relationship between the financial segment improvement and the development of the economic growth indicating that the development of the financial sector leads to the development of economic growth.

- $\quad$ There is a difference between results of the models regarding the short run: Using ARDL model a relation was found in the short run but using VAR model no relation was found in the short run.

So we can conclude that the choice of model has not effects on the results obtained in the long term. But in the short term we can have different results.

Model choice is vital part of the econometric modeling process. The results are then used for the decision making, forecasting, and many other problems. Regularly, the quality of these solutions depends on the goodness of the created econometric models.

By this study I am trying to calm econometricians and researchers and assure them that they can reach right results in the long run regardless the selection of the model but they have first to be based on some inference procedures like the maximum likelihood methods, generalized method of moments and so on. I will try this issue more and more in my future papers testing different relations in order to prove my point of view. 


\section{References}

Alomar Ibrahim. (2009). Ability of financial system to reduce poverty. MPRA Paper No. 18804 .Internet, http://mpra.ub.uni-muenchen.de/18804.

Caridi, Christy H. (2004). The Relationship between Credit Expansion, Inactive Balances, and the Capital Stock. Internet, http://www.newschool.edu/cepa/publications/workingpapers/archive/cepa

Copelman, Martina. (2000). Financial Structure and Economic Activity in Mexico. Center of Analysis and Economic Research. Internet, http://www.ITAM.com.

Eugene Iheanacho. (2016). The impact of financial development on economic growth in Nigeria: An ARDL analysis. Internet www.mdpi.com/2227-7099/4/4/26/pdf ( visited June 2017)

Gujarati, D. (2003). Basic econometrics, New York: McGraw-Hill Inc.

Hofmann, Boris. (2001).The Determinants of Private Sector Credit in Industrialized Countries: Do Property Prices Matter?. BIS Working Papers, No.108, Internet http://www.bis.org/publ/work108.htm (last visit September 2017).

Juliana Matei. (2020). Is financial development good for economic growth? Empirical insights from emerging European countries. Quantitative Finance and Economics, 4(4):653-678. Doi:10.3934/QFE.2020030

Mercan, M. and G. Ismet. (2013). "The effect of financial development on economic growth in BRIC-T countries: Panel data analysis." Journal of Economics and Social Studies. volume3. number1.

Naliniprava Tripathy. (2019). Does measure of financial development matter for economic growth in India?. Quantitative Finance and Economics, 3(3):508-525. Doi: 10.3934/QFE.2019.3.508.

Rania Ramadan Moawad. (2020)." ARDL Model to Test Relation between the Development of Financial Sector and the Economic Growth in Egypt". International Multilingual Journal of Science and Technology (IMJST) ISSN: 2528-9810 Vol. 5 Issue 7, July - 2020 
Rousseau Peter L. (2002). Historical perspectives on financial development and economic growth. Working Paper 9333. National bureau of economic research, Cambridge. Internet http://www.nber.org/papers/w9333 (Last visit 8/2017).

Rousseau Peter L. and Wachtel Paul. (2009). What is happening to the impact of financial Deeping on economic growth?. WIDER Working paper no. 09-w15.Vanderbilt university. Internet https://as.vanderbilt.edu/econ/wparchive/workpaper/vu09-w15.pdf.

\section{Data sources:}

Official site of the World Bank http://www.worldbank.org/en/publication/gfdr/data/global-financialdevelopment-database

Official website of the International Monetary Fund.

Data site www.theglobaleconomy.com/index_api.php. 